\title{
Developing On-line Quizzes Using Exelsa Moodle To Improve Student Achievement in Economic of Environment and Natural Resources Course
}

\author{
Kurnia Martikasari \\ Economic Education Study Program \\ Universitas Sanata Dharma, USD \\ Yogyakarta, Indonesia \\ nia.martika@usd.ac.id
}

\begin{abstract}
This research aims to develop on-line quizzes using exelsa moodle to improve student achievement in Economic of Environment and Natural Resources course. To collect data, students of Economic of Environmental and Natural Resources first degree in second semester 2015/2016 involved in the course quizzes. Data in this research is student result in on-line quizzes. The result showed that on-line quizzes using exelsa moodle could improve students' academic achievement in Economic of Environment and Natural Resources course.
\end{abstract}

Keywords - Economic of Environment and Natural Resources course, on-line quizzes, student achiement

\section{INTRODUCTION}

Indonesia is one of developing countries with rapid increasing in information and communication technology. It brings many impacts, especially in education. The role of technology in teaching and learning is rapidly becoming one of the most important and widely discussed issues in contemporary education policy [1]. Most experts in the field of education agreed that, when properly used, information and communication technology hold great promise to improve teaching and learning in addition to shaping workforce opportunities [1]. Trough the development of information and communication technology (ICT), students can get a lot of information both related to general knowledge and learning materials. Thus, a lecturer is not the only source of learning, but as a facilitator in learning. ICT requires that lecturer dan students must have high ability and skill in ICT in order to avoid many imbalance between science and human resources existing [2].

One of implementation ICT's in learning is e-learning. Elearning is a vast and some what disconnected area of inquiry that has attracted interest from disciplines as diverse as educational psycology, computer science, information science, management, communications, and more [3]. E-learning is any technologically mediated learning using computers whether from a distance or in face to face classroom setting (computer assisted learning), it is a shift from traditional education or training to ICT-based personalized, flexible, individual, selforganized, collaborative learning based on a community of learners, teachers, facilitators, experts [4]. E-learning is an electronic-based learning process using computer and internet networks that have no access restrictions, allowing lectures to be done with more time [5].
According Suyanto [6] e-learning is as follows.

- Utilizing the services of electronic technology, where teachers and learners, learners and learners, or teachers and fellow teachers can communicate with relative ease without being limited by the things.

- Utilizing the benefits of computers (digital media and computer networks).

- Use self-sustaining materials that can be stored on the computer so that they can be accessed by teachers and students anytime and anywhere when they need it.

- Utilize the learning schedule, curriculum, learning progress and matters relating to the administration of education that can be viewed at any time on the computer.

ICTs have the potential to accelerate, enrich, and deepen skills, to motivate and engage students, to help relate school experience to work practices, create economic viability for tomorrow's workers, as well as strengthening teaching and helping schools change. In a rapidly changing world, basic education is essential for an individual be able to access and apply information [7].

The uses of ICT is making major differences in the learning of students and teaching approaches. Several studies reveal that students using ICT facilities mostly show higher learning gains than those who do not use. Furthermore, the use of ICTs in education also shifts the learning approaches. With respect to introducing ICT technologies in education, Olson [in 8] advises to explore the following questions as bases for inservice teacher education. These are : how can the theoretical ideas tested in practice, what does practice say back to these theoretical ideas, how is useful negative feedbacks obtained, what might be substantive talking points about the new processes, what is practical from a classroom perspective, what does talking about the new say about the nature of existing technology, is it adequate, and what scaffold needs for the next stage [8].

ICT and digital technologies of e-learning can help learners improve learning efficiency and lecturers teach more efficiently [9]. For ICT to be integrated effectively, teachers need to first recognise what exactly ICT is and how it can enhance teaching and learning. ICT enables learners of all ages and abilities to explore, create and communicate [10]. 
Through ICT, learning can occur any time and anywhere [11]. Interaction between lecturers and students is not only done with direct face to face but also can use electronic media as an intermediary so that learning process becomes more interesting, visual and interactive [12]. In learning e-learning lecturers are guided to design effective learning strategies so that e-learning can further help students achieve learning objectives optimally.

\section{There are three components of e-learning [13]:}

\section{A. Infrastructure e-learning}

Infrastructure e-learning is a tool used in e-learning that can be a Personal Computer (PC), a privately owned computer, a computer network (ie, a collection of devices in the form of computers, switches, routers, or Other network devices connected by using certain communications media [6]), the Internet (is an abbreviation of Interconnection Networking defined as worldwide connected computers and multimedia equipment (media tools that combine two or more elements of media From integrated text, graphics, images, photos, audio, video and animation.) Including teleconference equipment (remote meeting between multiple people who are physically located in different geographical locations if we provide synchronous learning services ie learning process occurs at The same time when the teacher is teaching and the student is eLearning through teleconference.

\section{B. E-learning Systems and Applications}

E-learning systems and applications often referred to as the Learning Management System (LMS) are software systems that virtualize the conventional learning process for administration, documentation, reports of training programs, classrooms and on-line events, e-learning programs, And training content. For example, all features related to the learning process such as materials, videos, discussion forums, assignments, or assessments (quizzes) can be accessed with the internet.

\section{E-learning content}

Content e-learning is content and teaching materials that exist in e-learning system (Learning Management System). These content and teaching materials can be in the form of, for example, Multimedia-based Content or Text-based Content stored in Learning Management System (LMS) so that it can be run by learners anytime and anywhere.

Sanata Dharma University has E-Learning facility that is exelsa moodle. By using exelsa moodle, lecturer can interact with students without face to face. Lecturer can give materials subject, tasks, and online assessment.

The Economic of Environment and Natural Resources Course is one of the scientific and skills courses for the students of Economic Education, Faculty of Teacher Training and Education, Sanata Dharma University. This course is mandatory to pass the burden of 2 credits ( 2 hours lesson) for students of the sixth semester. The scope of the course is extensive, so it takes a lecture design that can help students understand the course material.
Based on the results of interviews from some students of the sixth semester participants in the Environmental Economic and Natural Resources course, there are two problems. The first problem is that they have not optimized moodle exelsa in learning. The second problem is that they have difficulties understanding the material with too much coverage.

Based on this problems, the authors interest to develop online quizzes using exelsa moodle in Economic of Environment and Natural Resources Course. On-line quizzes is best practise and helps improve developmental students' knowledge and skill. This research suggested that on-line quizzes migh be improve students' academic achievement in Economic of Environment and Natural Resources course.

\section{METHOD}

This research is a quasi experiment. Research periode is second semester 2015/2016 (February - June 2016). To collect data, students of Economic of Environment and Natural Resources first degree in second semester 2015/2016 involved in the course quizzes. Data in this research is student result in each on-line quizzes. Data analysis technique in this research is descriptive analysis.

\section{RESULTS AND DISCUSSION}

This research apply E-Learning in learning. E-learning can be used either as a stand-alone delivery tool or as a supplement to face-to-face instruction. This study focuses on the development of on-line quizzes to improve students' achievement in the Economic of Environment and Resources course. Data in this research is student result in on-line quizzes. The result is as follows.

TABLE I. STUDENTS RESULT IN ON-LINE QUIZZES

\begin{tabular}{|c|c|c|c|c|c|c|c|c|}
\hline GRADE & $\underset{1}{\text { QuIZ }}$ & $\begin{array}{c}\text { QUIZ } \\
2\end{array}$ & $\underset{3}{\text { QUIZ }}$ & $\underset{4}{\text { QUIZ }}$ & $\underset{5}{\text { QUIZ }}$ & $\begin{array}{c}\text { QUIZ } \\
6\end{array}$ & $\begin{array}{c}\text { QUIZ } \\
7\end{array}$ & $\begin{array}{c}\text { QUIZ } \\
8\end{array}$ \\
\hline $\begin{array}{c}\mathrm{A} \\
(80-100)\end{array}$ & 4 & 6 & 7 & 8 & 8 & 10 & 15 & 20 \\
\hline $\begin{array}{c}\mathrm{B} \\
(66-79)\end{array}$ & 8 & 8 & 6 & 8 & 7 & 15 & 12 & 7 \\
\hline$\underset{(56-65)}{\mathrm{C}}$ & 3 & 4 & 8 & 6 & 9 & & & \\
\hline$\underset{(46-55)}{\mathrm{D}}$ & 2 & 5 & 6 & 5 & 3 & 2 & 0 & 0 \\
\hline$\underset{(0-45)}{E}$ & 10 & 4 & & & & & & \\
\hline $\begin{array}{l}\text { PERCENTAGE } \\
\text { OFGRADE } \\
\text { A-C } \\
(\%)\end{array}$ & 55.56 & 66.67 & 77.78 & 81.49 & 88.89 & 92.59 & 100 & 100 \\
\hline
\end{tabular}


Based on table $\mathrm{I}$, result of this research shows that students received $\mathrm{C}$ and above grades (above or equal to 56) on the first on-line quiz is $55.56 \%$, increase in quiz 2 to $66.67 \%$, quiz 3 is $77.78 \%$, increase in quiz 4 ie $81.48 \%$, quiz 5 increase to $88.87 \%$, quiz 6 is $92.59 \%$, quiz 7 and quiz 8 increase to $100 \%$.

In the first quiz, the results showed that students who scored $\mathrm{C}$ and above grades (above or equal to 56) were $55.56 \%$ (15 students). This indicates that students who have sufficient material understanding in this course are $55.56 \%$ while the rest are not yet. In this first quiz, the results have not been satisfactory. This is due to several factors. Firstly, new students are first doing on-line quiz, so most students are still confused. This resulted in less students can do the quiz well so the result is less than the maximum. In this first quiz, there are also students who score $0(\mathrm{E})$ due to confusion in the work and time out.

In the second quiz, students who scored $\mathrm{C}$ and above grades (above or equal to 56) experienced an increase compared to the first quiz. Students who scored C and above were 66.68\% (18 students). This is because, students have already done on-line quiz on the first quiz, so the level of confusion is reduced.

In the 3-8 quiz, the quiz results are increasing. Result of quiz 3 is $77.78 \%$, increase in quiz 4 i.e $81.48 \%$, quiz 5 increase to $88.87 \%$, quiz 6 is $92.59 \%$, quiz 7 and quiz 8 increase to $100 \%$. This indicates that students are getting used to doing quiz and increasingly understand the Economic of Environment and Resources course.

On-line quizzes in each chapter did not only increase their achievement on each quiz, but also impacted the increase in the value of the Environmental Economics and Natural Resources exam. The results of the insertion test 1 , the insertion test 2 and the final test of the semester are as follows.

TABLE II. STUDENTS’ ACHIEVEMENT IN TEST

\begin{tabular}{|c|c|c|c|}
\hline GRADE & $\begin{array}{c}\text { INSERTIVE } \\
\text { TEST 1 }\end{array}$ & $\begin{array}{c}\text { INSERTIVE } \\
\text { TEST 2 }\end{array}$ & FINAL TEST \\
\hline $\begin{array}{c}\text { A } \\
(80-100)\end{array}$ & 4 & 11 & 14 \\
\hline $\begin{array}{c}\text { B } \\
(66-79)\end{array}$ & 8 & 10 & 10 \\
\hline $\begin{array}{c}\text { C } \\
(56-65)\end{array}$ & 3 & & 3 \\
\hline $\begin{array}{c}\text { D } \\
(46-55)\end{array}$ & 6 & 3 & \\
\hline $\begin{array}{c}\text { E } \\
(0-45)\end{array}$ & 8 & 2 & \\
\hline $\begin{array}{l}\text { PERCENTAG } \\
\text { E OF GRADE } \\
\text { A-C } \\
(\%)\end{array}$ & $55.56 \%$ & $77.78 \%$ & $100 \%$ \\
\hline
\end{tabular}

Table II shows that students received $\mathrm{C}$ and above grades (above or equal to 56) in the insertive test 1 is $55.56 \%$, in insertive test 2 increse to $77.78 \%$, and in final test is $100 \%$. It is mean that there is an increase in student learning outcomes seen from student exam results.

Based on the result of quiz and student exam score, it can be concluded that there is increasing understanding of students on the subject matter of Environmental Economics and Natural Resources. Thus, it can be concluded that on-line quizzes can improve students' achievement in the Economic of Environment and Natural Resource Course.

The results of this study are in line with Hardle's research, et al that e-learning can improve understanding of students and can be valuable for certain proportions [15].

\section{CONCLUSION}

This research is about developing on-line quizzes using exelsa moodle to improve student achievement in Economic of Environment and Natural Resources Course. Result of this research showed that on-line quizzes can improve students' achievement in Economic of Environment and Natural Resource Course. Based on this result, on-line quizzes can be used as an alternative media in the application of e-learning to improve students' achievement.

\section{ACKNOWLEDGEMENT}

Author would like to thank the Research Institute and Community Service of Sanata Dharma University, who like provided financial support in this research.

\section{REFERENCES}

[1] Ogiegbaen, Aduwa and Iymu. Using Information and Communication Technology in Secondary Schools in Nigeria: Problems and Prospects.Educationals Technology and Society, 8 (1), 2001, pp.104112.

[2] Agustina, Merry. Pemanfaatan E-Learning sebagai Media Pembelajaran. Yogyakarta: Seminar Nasional Aplikasi Teknologi Informasi (SNATI), 2013.

[3] Bell, Bradford S. And Jessica E. Federman. E-Learning in Postsecondary Education. The Future of Children, Vol. 23, No. 1, Postsecondary Education in the United State (SPRING 2013), pp. 165185. Accessed from : JSTOR.

[4] Jethro, Olojo Oludare, et al. E-Learning and Its Effects on Teaching and Learning in a Global Age. International Journal of Academic Research in Business and Social Sciences. January 2012, Vol.2, No. 1. Accessed from : JSTOR.

[5] Nugroho, W. A. E-Learning. February, 2017. [Online]. Accessed from: http://www.ilmukomputer.com.

[6] Suyanto. E-Learning. February, 2017. [Online]. Accessed from: www.ipi.or.id/elearn.pdf.

[7] Amin, Syed Noor-Ul. An Effective use of ICT for Education and Learning by Drawing on Worldwide Knowledge, Research, and 
Experience: ICT as A Change Agent for Education. [A Literature Review]. University of Kashmir: Department of Education.

[8] Mikre, Fisseha. The Roles of Information Communication Technologies in Education Review Article with Emphasis to the Computer and Internet. The Role of Information Communication. [Review Article].

[9] Chang, Maiga, et al. National Program for E-Learning in Taiwan. Journal of Educational Technology and Society, Vol.12, No.1, 2009. Accessed from JSTOR

[10] Gray, Tessa. Rich ICT Learning Experiences: What Do They Look Like? University of Waikato: ICT Adviser. [Article].

[11] Fu, Jo Shan. ICT in Education: A Critical Literature Review and Its Implications. International Journal of Education and Development Using Information and Communication Technology (IJEDICT), 2013, Vol.9, Issue 1, pp. 112-125. Singapore: National Institute of Education.
[12] Nuryanti, B. Lena. Model Pembelajaran E-Learning melalui Homepage sebagai Media Pembelajaran sehingga Diharapkan dapat meningkatkan Minat dan Kreatifitas Siswa. April, 2017. [Online]. Accessed from: http://download.portalgaruda.org/article.php?article=95150\&val=576.

[13] Romisatriawahono. Virtual Class. February, 2017. [Online]. Accessed from: http://www.romisatriawahono.net /2008/01/23

[14] Brothen, Thomas and Catrine Wambach. Internet vs Classroom Access in a Hybrid Psychology Course for Developmental Students. Research and Teaching in Developmental Education, Vol. 23, No 2 (Spring 2007), pp.15-22. Accessed from: JSTOR.

[15] Hardle, Wolfgang, et al. On the Utility of E-Learning in Statistics. International Statistical Review / Revue Internationale de Statistiqe, Vol.75, No 3 (December 2007), pp. 355-364. Accessed from: JSTOR. 